\title{
The Weight of History on European Cultural Integration: a Gravity Approach
}

\author{
Pauline Grosjean ${ }^{1}$
}

December 27, 2010

Cultural integration is a European obsession. Given the growing evidence on the role of culture as a determinant of economic development, this issue is of importance to economists. Some literature hypothesizes that the variation of the relative strengths of cultural assimilation and differentiation gave rise to different patterns of economic development (Ashraf and Galor 2007), while other emphasizes the importance of specific cultural traits for institutional and economic development. Among those, social trust has received particular attention. Recently, the literature has looked into the historical origins of social trust, relating contemporary cross regional differences in trust to historical events such as the free city states experiences in Northern Italy (Tabellini 2008, Guiso et al. 2008) or the slave trades in Africa (Nunn and Wantchekon forth). Going even further back in time, Durante (2010) link current regional differences in trust to climatic variability since the year 1500 . While such evidence on the long term persistence of cultural traits is intriguing, little remains understood concerning the rate at which cultural values change under the influence of such historical events.

Cultural persistence and cultural heterogeneity are the two sides of the same coin. Historians have hypothesized that one reason behind the complexity of European integration may be the fact that Europe, as opposed to China or North America, has never experienced a single unifying historical experience (Blockmans 2006). The model in this paper estimates the contribution to cultural integration, or its counter side heterogeneity, of a long history of division between the Ottoman, Habsburg, Russian or Prussian Empires in 21 countries of Central, Eastern and SouthEastern Europe. By exploiting the variation in the length of integration of different localities in different empires, this papers sheds light not only on the influence of political integration on cultural integration but also on the rate of cultural change.

This paper confirms that, indeed, history matters, even when spatial proximity or formal institutions are taken into account and that cultural evolution is very slow. A lasting and

\footnotetext{
${ }^{1}$ University of San Francisco. I am thankful to Alberto Bisin, Mathieu Couttenier, Raquel Fernandez, Luigi Guiso, Jeremy Magruder, Thierry Mayer, Edward Miguel, Martin Raubal, Gerard Roland, Claudia Senik, Thierry Verdier and all participants at the NBER Summer Institute in Political Economy, the CEPR conference on models of cultural diversity and the UC Berkeley development lunch for helpful comments and suggestions. The financial supports of the Ciriacy Wantrup foundation and of CEPREMAP are greatly appreciated.
} 
significant effect of living under common institutions on social trust comes after 400 years of imperial rule. By contrast, more recent history, such the former USSR or Yugoslavia, is not significantly associated with a reduction in cultural distances in terms of social trust. Even more strikingly, neither is the delimitation of current nation states, once history and geographic proximity are taken into account.

The rest of the paper is organized as follows. Section 1 presents a gravity model of cultural integration and the data. Section 2 presents the results. Section 3 concludes. More details on the model specification as well as all descriptive statistics, complete results and additional specifications are included in a web appendix.

\section{A Gravity Model of Cultural Integration, History and Data}

To study the determinants of cultural integration, this paper proposes a gravity approach. The model is an adaptation of a trade gravity model, which explains different intensities of trade integration as a function of the proximity of trading partners, respective and common characteristics of locations. In this 'cultural gravity model', different intensities of cultural integration are regressed on common characteristics of localities, such as shared history or common contemporaneous institutions, controlling for spatial proximity between locations and respective socio-demographic characteristics. An interesting application of this approach is that it is possible to use a common metric (kilometers) in order to quantify the respective contributions of the different determinants of cultural values that have been discussed in the literature, such as history but also physical proximity (Tabellini 2008, Giulano, Spilimbergo and Tonon 2006), religion (Barro and McLeary 2003) or current institutions and democratization (Grosjean and Senik forth.). Some of these determinants are likely to be correlated with history. For example, locations that are physically close are more likely to have experienced a common history. Also, part of the legacy of history may be captured through formal institutions. The dyadic model used in this paper makes it possible for controlling for such factors, what is important to determine whether the effect of history is not confounded by that of physical proximity or goes beyond any legacy of history on formal institutions.

The data comes from the Life in Transition Survey (LITS), conducted by the World Bank and the European Bank for Reconstruction and Development in 2006 in Central, Eastern and South Eastern Europe. The analysis is at the sub-national level of a primary sampling unit, which 
corresponds to a village or suburb. There are 50 PSUs in each of 21 countries retained for analysis. The model can be applied to a variety of measures of culture but the focus here is on social trust. The dependent variable reflects the absolute value of the difference between pairs of locations in average responses to the widely used general trust question: "Generally Speaking, would you say that most people can be trusted, or that you can't be too careful in dealing with people?". The unit of observation is a PSU pair.

The analysis takes advantage of three particularly appealing features of the data.

First, the region covered by the survey, with the notable exception of the central region of Montenegro, was divided, since the beginning of the $14^{\text {th }}$ century and until the eve of the first World War between the Ottoman Empire, the Austro Hungarian Empire, Prussia and the Russian Empire, and the boundaries of the different empires shifted repeatedly. I exploit the variation in the length of integration of different localities into different empires in order to shed light on the rate of cultural change. The Ottoman Empire's territorial extension in South-Eastern Europe occurred in the XIVth and XVth century and lasted until the Russian-Turkish War of 1877-1878 and the Balkan Wars of 1911-1912. The Austro Hungarian Empire includes what was the Kingdom of Hungary and the Austrian Empire and became the Austria-Hungarian Empire after the 1867 Ausgleich. Successor states became independent after the Saint-Germain and Sevres treaties of 1918. Prussia encompasses Prussia per se (1525-1947) as well as Old Prussia (the Teutonic Order). Most Prussian territories outside of today's Germany were lost at the Treaty of Versailles in 1919. The Russian Empire's territorial expansion in Europe occurred mainly under Peter the Great and Catherine the Great in the XVII ${ }^{\text {th }}$ and XVIIIth centuries. I use the Periodical Atlas of Europe in order to reconstruct empires' delimitations and their evolution across time, from 1300, the start of empire consolidation in Medieval Europe, to 2000. The influence of history is reflected through different dummy variables, which reflect how long each locality pair was included in the same empire for. The minimum length of integration is 100 years and the maximum 700 years.

Second, most successor states borders do not coincide with former empires' borders. This is key to distinguish the legacy of history on culture from its legacy on current institutions.

Third, LITS contains precise localization data and a very rich set of attitudinal questions and socio economic background information, which allows for controlling for several determinants of cultural distance discussed above. 


\section{Results and Applications}

\section{A. The Long Term Effects of History}

Table 1 present estimation results of the 'cultural gravity model', in which the dependent variable reflects differences among location-pairs in terms of general trust. A higher value of the dependent variable reflects more cultural heterogeneity.

Table 1: Results

\begin{tabular}{|c|c|c|c|c|c|c|}
\hline & 1 & 2 & 3 & 4 & 5 & 6 \\
\hline Dependent variable: & \multicolumn{6}{|c|}{ Cultural Distance: General Trust } \\
\hline Same Empire more 100 years & $\begin{array}{c}-0.061^{*} \\
{[0.008]}\end{array}$ & & $\begin{array}{l}-0.042 * \\
{[0.007]}\end{array}$ & & $\begin{array}{l}-0.041^{*} \\
{[0.007]}\end{array}$ & $\begin{array}{l}-0.041^{*} \\
{[0.007]}\end{array}$ \\
\hline Same Empire 100 to 200 years & & & & $\begin{array}{l}-0.011 \\
{[0.010]}\end{array}$ & & \\
\hline Same Empire 200 to 400 years & & & & $\begin{array}{l}-0.003 \\
{[0.011]}\end{array}$ & & \\
\hline Same Empire more 400 years & & & & $\begin{array}{l}-0.090^{*} \\
{[0.018]}\end{array}$ & & \\
\hline USSR & & & & & $\begin{array}{c}-0.016 \\
{[0.007]}\end{array}$ & \\
\hline Yugoslavia & & & & & $\begin{array}{l}0.016^{* *} \\
{[0.007]}\end{array}$ & \\
\hline EU & & & & & & $\begin{array}{l}-0.004 \\
{[0.009]}\end{array}$ \\
\hline Distance & & & $\begin{array}{l}0.031^{*} \\
{[0.004]}\end{array}$ & $\begin{array}{l}0.032^{*} \\
{[0.004]}\end{array}$ & $\begin{array}{l}0.031^{*} \\
{[0.005]}\end{array}$ & $\begin{array}{l}0.027^{*} \\
{[0.004]}\end{array}$ \\
\hline Same country & & $\begin{array}{l}-0.066^{*} \\
{[0.008]}\end{array}$ & $\begin{array}{c}0.008 \\
{[0.009]}\end{array}$ & $\begin{array}{c}0.013 \\
{[0.010]}\end{array}$ & & $\begin{array}{l}0.008 \\
{[0.009]}\end{array}$ \\
\hline Contiguous & & $\begin{array}{c}-0.026^{* *} \\
{[0.006]}\end{array}$ & $\begin{array}{c}0.009 \\
{[0.006]}\end{array}$ & $\begin{array}{c}0.015 \\
{[0.007]}\end{array}$ & & $\begin{array}{c}0.002 \\
{[0.005]}\end{array}$ \\
\hline Socio-demo and eco controls & yes & yes & yes & yes & yes & yes \\
\hline Observations & 535095 & 535095 & 535095 & 535095 & 535095 & 535095 \\
\hline R-squared & 0.445 & 0.444 & 0.447 & 0.472 & 0.447 & 0.447 \\
\hline
\end{tabular}

Notes: The dependent variable is the Manhattan distance measure of dissimilarity between PSU pairs in responses to the general trust question. Distance is expressed as the logarithm of the physical distance between PSUs in km. The Same Empire... dummies takes value 1 if both PSUs have belonged to the same Empire for the number of years indicated. Same Country and Contiguity are dummy variables that take value 1 if members of the pair belong to, respectively, the same country or adjacent countries. Socio-demo and eco controls are Manhattan distance measures of dissimilarity between pairs of PSUs in terms of religious affiliation, social class composition, education, age, industrial index and occupations. In Column 6, variables that reflects whether members of the PSU pair are both candidate countries or whether one PSU belongs to a member states while the other to a candidate country are included but the results are omitted. All regressions include a constant and location fixed effects. Robust standard errors are adjusted for clustering on any observation that contains either member of a pair, following the multi-way clustering method by Cameron et al. (2010). * indicates significance at $1 \%,{ }^{* *}$ at $5 \%$. Source: Life in Transition Survey 2009; Periodical Atlas of Europe 1300-2000. 
History matters. Having belonged to the same former Empire for more than 100 years has the consistent and robust effect of diminishing dissimilarities in general trust, even when physical distance between locations, socio-demographic, economic and geopolitical conditions are taken into account. Such a persistent effect of past historical events, which are quite distant in time, is notable and sizeable and, strikingly, far outweighs the influence of current geopolitical factors, in particular nation states' borders. Indeed, the Same Country and Contiguity dummies, although significant and of the expected negative sign when included on their own (Column 2), lose significance when spatial proximity between locations and history are taken into account (Column 3). This may be explained by the fact that in this region, borders are quite recent -most borders were determined after the first World War or after the collapse of the Soviet Union and Yugoslavia- and, in many cases, arbitrary. Still, this is a striking result in light of the strong country fixed effects that come out of cross country cultural comparisons, which generally ignore the role of history and the spatial processes of cultural diffusion.

In order to shed light on the rate of cultural change, the Same Empire dummy is separated into three different dummies indicating whether two locations spent 100 to 200 years, 200 to 400 years, or more than 400 years in the same Empire (Column 4). The results illustrate the very slow nature of cultural change. The effect of history is not significant for less than 400 years of common Imperial rule. Among the different empires, the Ottoman Empire and, to a lesser extent, Prussia are the most influential (see Web appendix). A different specification of the model, in which the dependent variable reflects the direction in which history effects general trust illustrates that the former Ottoman Empire has left a significantly negative imprint on general trust in South Eastern Europe.

It is interesting to express the influence of each variable in terms of a common metric. Integration in the same empire for more than 100 years 'reduces' cultural distance between two PSUs, in terms of general trust, by the equivalent of $1394 \mathrm{~km} .^{2}$ The average physical distance between two locations in the sample is $1029 \mathrm{~km}$. At the sample average, having belonged to the same empire reduces this distance by $349 \mathrm{~km}$. By contrast, differences in religions increase the distance by $499 \mathrm{~km}$, at the sample average.

\footnotetext{
${ }^{2} 10.29 *(-0.042 /(0.031 / 100)) .10 .29$ is equivalent to a one percent change in average distance.
} 
Most of the other covariates have expected positive signs: dissimilarities in terms of social class composition, education, gender composition, religion or differences in industrial development contribute positively to cultural distance in general trust and dissimilarity in economic occupations. Additional specifications show that the presence of geographical obstacles such as mountain ranges or differences in the degree of democratization between countries are significantly associated with larger cultural differences, but the effect of history remains robust to such additional controls.

\section{B. More recent history: USSR, Yugoslavia and the European Union}

Column 5 of Table 1 investigates the influence of more recent history. The variables USSR and Yugoslavia take value 1 if both locations in the pair used to belong to, respectively, the former USSR and former Yugoslavia. Strikingly, the former USSR appears to have no significant lasting effect on the differences in general trust. This is nevertheless in line with the previous result that it takes 400 years of political integration in order to have a sizeable impact on individual trust values. For the former Yugoslavia, the coefficient on general trust is positive, indicating greater dissimilarity. One reason could be the influence of war, a shocking enough event to have had such an impact, even in a short time span.

Several countries in our sample are also either member states of the European Union (EU) or candidate countries. Several dummy variables are constructed in order to reflect the status of each country in our sample relative to the EU. Results are displayed in Column 6. There is no significant relationship between EU integration and similarity in terms of general trust.

\section{Conclusion}

This cultural gravity model provides a tool to investigate the determinants of cultural integration and can be applied to many dimensions of cultural integration. Here, the focus is on general trust, but the model could be applied to, for instance: the pattern of economic occupations, preferences for redistribution, corruption, or female labor force participation.

The main message of the paper is that history matters and cultural change is very slow. The significant effect of living under common institutions on the pattern of general trust appears after 400 years of common history. The Ottoman Empire has left the largest imprint on cultural values in the region. Shorter, albeit more recent events, such as the USSR, EU membership or even 
nation states are not significantly associated with general trust outcomes. This is consistent with the literature stressing that culture is a slow moving institution (Roland 2004). For economic occupations however, additional results show that things move faster: the effect of past empires is observed after "only" 200 years of common institutions, and the USSR, Yugoslavia or EU membership are significantly associated with the pattern of economic occupations.

The results also confirms not only that both history and spatial proximity play a role in cultural transmission but that they are also correlated. This implies that proxying cultural distance by history alone and ignoring the impact of physical proximity will result in overestimating the impact of history, and vice versa. Similarly, ignoring physical proximity and history altogether, for example by treating country averages as independent observations will result in a large bias. In particular, country fixed effects will be overestimated. This paper cautions against the use of national averages for cross-country comparisons in cultural studies. 


\section{References}

Ashraf, Quamrul and Oded Galor. 2007. "Cultural Assimilation, Cultural Diffusion, and the Origin of the Wealth of Nations." Working Paper 2007-03, Brown University.

Barro, Robert J., and Rachel M. McCleary. 2003. "Religion and Economic Growth Across

Countries." American Sociological Review, 68(5): 760-781.

Blockmans, Wim. 2006. "Europe's History of Integration and Diversity." European Review, 14(2): 241-256.

Cameron, Colin, Jonah B. Gelbach and Douglas L. Miller. Forthcoming. "Robust Inference with Multi-way Clustering." Journal of Business and Economic Statistics.

Durante, Ruben. 2010. "Risk, Cooperation and the Economic Origins of Social Trust: an Empirical Investigation.” Mimeo, Sciences-Po.

Giuliano, Paola, Antonio Spilimbergo and Giovanni Tonon. 2006. "Genetic, Cultural and Geographical Distances.” IZA Discussion Papers 2229.

Grosjean, Pauline and Claudia Senik. Forthcoming. "Democracy, Market Liberalization and Political Preferences." Review of Economics and Statistics.

Guiso, Luigi, Paola Sapienza and Luigi Zingales. 2008. "Long Term Persistence.” NBER Working Papers 14278.

Nunn, Nathan and Leonard Wantchekon. Forthcoming. "The Slave Trade and the Origins of Mistrust in Africa." American Economic Review.

Roland, Gerard. 2004. "Understanding Institutional Change: Fast-Moving and Slow-Moving Institutions.” Studies in Comparative International Development, 38(4): 109-131.

Tabellini, Guido. 2008. "The Scope of Cooperation: Values and Incentives." Quarterly Journal of Economics, 123(3): 905-950. 


\section{Web Appendix}

\section{A. Empirical Model and Definition of variables:}

As usual in the trade gravity literature, the relationship between cultural distance and physical distance is assumed to be concave and the following dyadic model is estimated:

$$
D C_{\mathrm{ln}}=\alpha_{1} E+\alpha_{2} \ln \left(D I S T_{\mathrm{ln}}\right)+\alpha_{3} I+\alpha_{4} C+\alpha_{5} D S_{\mathrm{ln}}+\alpha_{6} D O_{\mathrm{ln}}+\alpha_{7} D R_{\mathrm{ln}}+\alpha_{8} D I_{\mathrm{ln}}+\delta_{l}+\delta_{n}+\varepsilon_{\mathrm{ln}}
$$

where the MD variables are metrics of dissimilarity between pairs of locations $l$ and $n$. Manhattan Distances, which sum over the absolute differences in shares of responses for multinomial variables (Head and Mayer 2008) are used throughout. $D C_{\mathrm{ln}}$ is defined as: $D C_{\mathrm{ln}}=\sum_{i=1}^{I}\left|s_{i l}-s_{i n}\right|$ where $s_{i l}$ (respectively $s_{i n}$ ) is the share, in location $l$ (respectively $n$ ) of responses allocated to each modality $i$ of the $I$ modalities of the following widely used question on general trust, which was replicated in the Life in Transition Survey: "Generally Speaking, would you say that most people can be trusted, or that you can't be too careful in dealing with people?" Responses modalities are on a scale of 1 to 5 , with 1 corresponding to "Complete Distrust" and 5 to "Complete Trust".

Vertical transmission of preferences from parents to children implies some hysteresis in the transmission of preferences, which explains why history matters (Bisin and Verdier, 2001; Tabelini, 2010). The influence of history is reflected through different dummy variables $E$, which reflect how long each locality pair was included in the same empire for (see Section 2). The minimum length of integration is 100 years and the maximum 700 . A similar past history is expected to decrease cultural distance so that $\alpha_{1}$ is expected to be negative.

The next covariate in (1) examines the role of geographic distance between locations. The geographical distance between members of PSU pairs is computed from longitudinal and latitudinal coordinates of the geographical center of the PSU using the great circle formula. Since geographic distance is an obstacle to cultural diffusion, so that $\alpha_{2}$ is expected to be positive. As usual in the gravity trade models, $I$ is a dummy variable indicating whether the two districts are located in the same country and $C$ is a dummy variable to indicate whether two locations belong to different but adjacent countries.

Controls include dissimilarities between location pairs in terms of income $\left(D I_{\mathrm{ln}}\right)$, education ( $\left.D E_{\mathrm{ln}}\right)$, religion $\left(D R_{\mathrm{ln}}\right)$, economic occupations $\left(D O_{\mathrm{ln}}\right)$ and the characteristics of the local 
economy $\left(D I_{\mathrm{ln}}\right)$. To reflect differences in the characteristics of the local economy, I use the index developed by Grosjean and Senik (forth) that captures the development of the modern sector of the economy and the advancement towards a market economy. ${ }^{3}$ The categories used in the construction of the Manhattan distance in occupations are the following: unemployed; pensioner; student; housewife; or employed, with this last category broken up in different subcategories of: white collar, blue collar, service worker and farmer or farm-worker. The different categories of employment were constructed from the responses about the respondent's first job, using the ISCO classification. ${ }^{4}$ Differences between PSUs in the age and gender of respondents are also included as controls.

Finally, the regression specification includes an error term and a set of intercepts for each location (Primary Sampling Unit). The fixed effects are designed to capture third-location effects on the pairwise differences (Head and Mayer 2008). Also, to account for the fact that standard errors are correlated among every pair that contains a specific observation, standard errors are adjusted for clustering on any observation that contains either member of a pair, following the multi-way clustering method by Cameron et al. (2010).

\section{B. History}

The main historical event of interest is the integration of localities in the former Empires of Central, Eastern and South Eastern Europe: the Ottoman Empire, the Habsburg Empire, Prussia (and the Teutonic Order) and the Russian Empire, which occupied all the localities in the sample (with the notable exception of Upper Zeta, the central region of Montenegro). The Ottoman Empire's territorial extension in South-Eastern Europe occurred mainly in the XIVth Century (Bulgaria, South Serbia, FYROM) and the XVth century (Albania, Bosnia and Herzegovina, Crimea, Moldavia, Wallachia and Montenegro). Territorial losses of the Ottoman Empire occurred chiefly in two waves: at the end of the XIXth century, after the Russian-Turkish War of 1877-1878, and after the Balkan Wars of 1911-1912. I designate by 'Habsburg Empire' what

\footnotetext{
${ }^{3}$ This index ("industrial index") measures the proportion of respondents in the active labor force who are selfemployed with more than five employees, or have a formal labor contract and either: work in a small enterprise, work in a medium enterprise, work in a private firm, work in a newly created enterprise (since 1989).

${ }^{4}$ The ISCO categories corresponding to our white collar category are: 1: Legislator, Senior Official and Manager, 2: Professionals, and 3: Technicians and Associated Professionals. Our service workers category consists of: 4: Clerks and 5: Service workers and shop and market sales workers. 6: Skilled agricultural and fishery workers are in our "farmer and farm worker category" together with independent farmers. All the remaining ISCO categories are considered as blue collar workers.
} 
was the Kingdom of Hungary and the Austrian Empire and became the Austria-Hungarian Empire after the 1867 Ausgleich. Successor states became independent after the Saint-Germain and Sevres treaties of 1918 and include territories that now belong to Croatia, Hungary, the Czech Republic, Poland, Romania, the Slovak Republic, Slovenia, Serbia and Ukraine. 'Prussia' designate Prussia per se (1525-1947) as well as Old Prussia (the Teutonic Order). Prussia encompassed territories that are today part of Poland, Lithuania and Czech Republic, as well as Germany, Denmark, Belgium and the Netherlands (not included in our sample). Most territories outside of today's Germany were lost at the Treaty of Versailles in 1919. The Russian Empire's territorial expansion in Europe occurred mainly under Peter the Great in the XVII ${ }^{\text {th }}$ century and Catherine the Great in the XVIIIth century. Bessarabia was gained from the Ottomans in 1812. The Russian Empire encompassed more or less the Soviet Union, with the addition of Polish territories, Turkish territories, but a much smaller Ukraine, not all territories of the Baltic states and without Kaliningrad. I use the Periodical Atlas of Europe in order to reconstruct Empire delimitations and their evolution across time, from 1300, the start of empire consolidation in Medieval Europe, to 2000. Table A2 presents some descriptive statistics on the length and geographical delimitation of these empires. 


\section{Descriptive Statistics and Additional Results}

\section{Descriptive Statistics}

Figure A1. Map of Dynastic Empires in Central and Eastern Europe

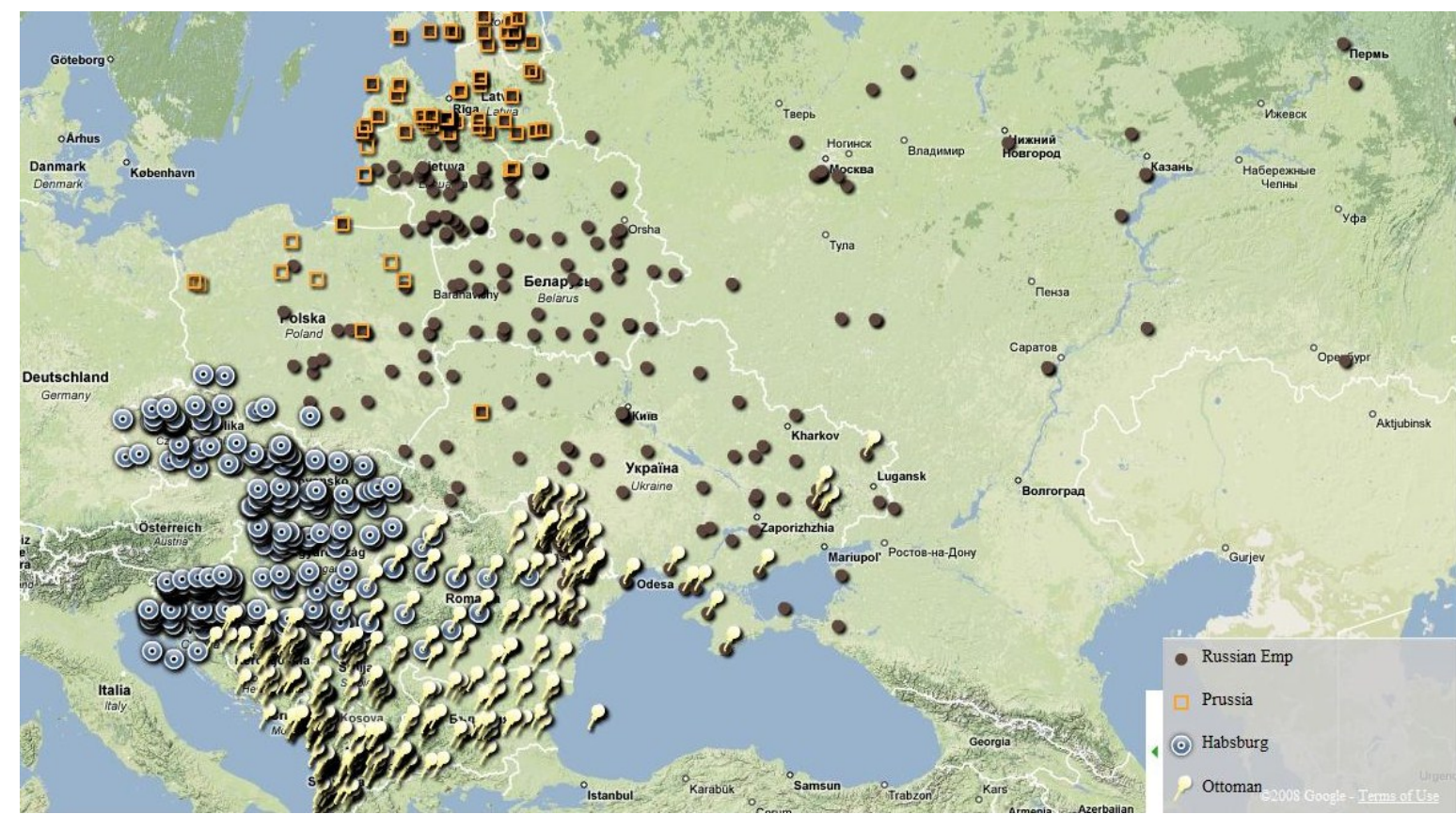

Notes to Figure A1: The figure indicates PSUs that belonged to the Russian, Prussian, Habsburg and Ottoman Empires for more than 200 years only in Central, Eastern and South Eastern Europe. Source: Periodical Atlas of Europe 1300-2000.

Table A1: List of countries included in the sample

Albania, Belarus, Bosnia and Herzegovina, Bulgaria, Croatia, Czech Republic, Estonia, Former Yugoslav Republic of Macedonia, Hungary, Latvia, Lithuania, Moldova, Montenegro, Poland, Romania, Russian Federation, Serbia, Slovak Republic, Slovenia, Turkey, Ukraine. 
Table A2: Geographical and temporal delimitations of Empires in the sample

\begin{tabular}{|c|c|c|c|}
\hline & 400 years or more & 200 to 400 years & 200 years or less \\
\hline $\begin{array}{l}\text { Ottoman } \\
\text { Empire }\end{array}$ & $\begin{array}{l}\text { Albania, Sancak of } \\
\text { Bosnia, Bulgaria } \\
\text { (except part which } \\
\text { became } \\
\text { independent in } \\
\text { 1878), FYROM, } \\
\text { Turkey }\end{array}$ & $\begin{array}{l}\text { Rest of Bosnia, } \\
\text { Bulgaria which became } \\
\text { independent in } 1878 \text {, } \\
\text { Bessarabia, Crimea, } \\
\text { Moldavia, outer } \\
\text { Montenegro, Serbia } \\
\text { except Vojvodina, } \\
\text { Wallachia }\end{array}$ & $\begin{array}{l}\text { Transylvania, Vojvodina, } \\
\text { southern Hungary, eastern } \\
\text { Croatia }\end{array}$ \\
\hline $\begin{array}{l}\text { Habsburg } \\
\text { Empire }\end{array}$ & $\begin{array}{l}\text { Slovakia, Hungary } \\
\text { (except southern- } \\
\text { ottoman Hungary) }\end{array}$ & $\begin{array}{l}\text { Croatia (except } \\
\text { Dalmatia), Czech } \\
\text { Republic, Southern } \\
\text { (ottoman) Hungary, } \\
\text { Polish Silesia, } \\
\text { Slovenia, Transylvania, } \\
\text { Vojvodina }\end{array}$ & $\begin{array}{l}\text { Dalmatia, Galicia, Habsburg } \\
\text { Poland (Krakow, Rzeszow), } \\
\text { Bosnia, western Ukraine } \\
\text { (Lviv) }\end{array}$ \\
\hline Prussia & $\begin{array}{l}\text { Pomerania } \\
\text { (Poland) }\end{array}$ & $\begin{array}{l}\text { Estonia, Latvia, Polish } \\
\text { Silesia, Royal Prussia }\end{array}$ & $\begin{array}{l}\text { Polish Silesia, Kaliningrad, } \\
\text { Klaipeda (Lithuania) }\end{array}$ \\
\hline $\begin{array}{l}\text { Russian } \\
\text { Empire }\end{array}$ & & $\begin{array}{l}\text { Russia (except } \\
\text { Kaliningrad), Ukraine } \\
\text { (except Crimea and } \\
\text { Kouban) }\end{array}$ & $\begin{array}{l}\text { Belarus, Baltic states (except } \\
\text { Klaipeda), Moldova, eastern- } \\
\text { central Poland (Warsaw, } \\
\text { Lodz), rest of Ukraine }\end{array}$ \\
\hline
\end{tabular}

Source: Periodical Atlas of Europe 1300-2000 
Table A3: Descriptive statistics

\begin{tabular}{|c|c|c|c|c|c|}
\hline Variable & Description & Mean & s.d.. & Min & Max \\
\hline General trust & Manhattan Distance general trust & 0.87 & 0.37 & 0 & 2 \\
\hline Occupation & Manhattan Distance Occupation & 0.89 & 0.31 & 0.04 & 2.48 \\
\hline Same Empire & $\begin{array}{l}\text { Dummy }=1 \text { if PSU pair in same former dynastic empire } \\
\text { (Habsburg, Ottoman, Prussia and Russian Empires) for } \\
\text { more than } 100 \text { years }\end{array}$ & 0.25 & 0.43 & 0 & 1 \\
\hline Distance in $\mathrm{km}$ & distance between 2 PSUs (in km ) & 1029 & 783 & 0 & 12737 \\
\hline Distance & Logarithm of distance in $\mathrm{km}$ & 6.66 & 0.83 & 0 & 9.45 \\
\hline MD religion & $\begin{array}{l}\text { Manhattan distance for main religions (Muslim, Christian, } \\
\text { Jewish, other religion and Atheist) }\end{array}$ & 0.79 & 0.71 & 0 & 2 \\
\hline MD social class & $\begin{array}{l}\text { Manhattan distance of proportions of rich, poor and middle } \\
\text { income }\end{array}$ & 0.65 & 0.36 & 0 & 2 \\
\hline MD education & Manhattan distance education (5 education categories) & 0.89 & 0.37 & 0 & 2 \\
\hline Difference in age & Absolute value of difference in average age of PSUs & 8.12 & 6.14 & 0 & 49.46 \\
\hline MD labor index & $\begin{array}{l}\text { Absolute value of the difference in the proportion of } \\
\text { respondents in the active labor force who are self-employed } \\
\text { with more than five employees, or have a formal labor } \\
\text { contract and either: work in a small enterprise, work in a } \\
\text { medium enterprise, work in a private firm, work in a newly } \\
\text { created enterprise (since 1989) }\end{array}$ & 0.58 & 0.45 & 0 & 3.61 \\
\hline Same country & Dummy $=1$ if PSU pair in same country & 0.05 & 0.21 & 0 & 1 \\
\hline Contiguous & Dummy $=1$ if PSU pair in adjacent countries & 0.17 & 0.38 & 0 & 1 \\
\hline $\begin{array}{l}\text { Same Empire for } \\
100 \text { to } 200 \text { years }\end{array}$ & $\begin{array}{l}\text { Dummy }=1 \text { if PSU pair in same former dynastic empire } \\
\text { (Habsburg, Ottoman, Prussia and Russian Empires) for } \\
\text { between } 100 \text { and } 200 \text { years }\end{array}$ & 0.12 & 0.32 & 0 & 1 \\
\hline $\begin{array}{l}\text { Same Empire for } \\
200 \text { to } 400 \text { years }\end{array}$ & $\begin{array}{l}\text { Dummy }=1 \text { if PSU pair in same former dynastic empire } \\
\text { (Habsburg, Ottoman, Prussia and Russian Empires) for } \\
\text { between } 100 \text { and } 200 \text { years }\end{array}$ & 0.03 & 0.16 & 0 & 1 \\
\hline $\begin{array}{l}\text { Same Empire for } \\
\text { more than } 400 \\
\text { years }\end{array}$ & $\begin{array}{l}\text { Dummy }=1 \text { if PSU pair in same former dynastic empire } \\
\text { (Habsburg, Ottoman, Prussia and Russian Empires) for } \\
\text { more than } 400 \text { years }\end{array}$ & 0.05 & 0.21 & 0 & 1 \\
\hline $\begin{array}{l}\text { Habsburg } \\
\text { Empire }\end{array}$ & $\begin{array}{l}\text { Dummy }=1 \text { if PSU pair in the Habsburg Empire for more } \\
\text { than } 100 \text { years }\end{array}$ & 0.12 & 0.32 & 0 & 1 \\
\hline Ottoman Empire & $\begin{array}{l}\text { Dummy }=1 \text { if PSU pair in the Ottoman Empire for more } \\
\text { than } 100 \text { years }\end{array}$ & 0.20 & 0.40 & 0 & 1 \\
\hline Prussia & Dummy $=1$ if PSU pair in Prussia for more than 100 years & 0.014 & 0.12 & 0 & 1 \\
\hline Russian Empire & $\begin{array}{l}\text { Dummy }=1 \text { if PSU pair in the Russian Empire for more } \\
\text { than } 100 \text { years }\end{array}$ & 0.12 & 0.32 & 0 & 1 \\
\hline USSR & Dummy $=1$ if PSU pair in former USSR & 0.11 & 0.31 & 0 & 1 \\
\hline Yugoslavia & Dummy $=1$ if PSU pair in former Yugoslavia & 0.08 & 0.27 & 0 & 1 \\
\hline EU & Dummy =1 if PSU pair in European Union (EU) & 0.23 & 0.42 & 0 & 1 \\
\hline EU candidate & Dummy $=1$ if PSU pair in candidate countries to EU & 0.01 & 0.12 & 0 & 1 \\
\hline $\begin{array}{l}\text { EU-EU } \\
\text { candidate }\end{array}$ & Dummy $=1$ if 1 PSU in EU, the other in candidate country & 0.14 & 0.34 & 0 & 1 \\
\hline
\end{tabular}

Source: Life in Transition Survey 2009; Periodical Atlas of Europe 1300-2000. 


\section{Additional Results}

Table B1: Results of Full Specification

\begin{tabular}{|c|c|c|c|c|}
\hline & 1 & 2 & 3 & 4 \\
\hline & \multicolumn{4}{|c|}{ Manhattan Distance General Trust } \\
\hline \multirow[t]{2}{*}{ Distance } & $0.030 * * *$ & $0.031 * * *$ & $0.028 * * *$ & $0.030 * * *$ \\
\hline & {$[0.003]$} & {$[0.004]$} & {$[0.003]$} & {$[0.004]$} \\
\hline \multirow[t]{2}{*}{ Same Empire more than 100 years } & $-0.046 * * *$ & $-0.047 * * *$ & $-0.041 * * *$ & $-0.041 * * *$ \\
\hline & {$[0.008]$} & {$[0.008]$} & {$[0.007]$} & {$[0.007]$} \\
\hline \multirow[t]{2}{*}{ Same country } & & -0.002 & & $0.006^{* *}$ \\
\hline & & [0.009] & & {$[0.009]$} \\
\hline \multirow[t]{2}{*}{ Contiguous } & & 0.008 & & $0.008 * * *$ \\
\hline & & {$[0.006]$} & & {$[0.006]$} \\
\hline \multirow[t]{2}{*}{ Presence of mountain range } & & & & $0.016^{* *}$ \\
\hline & & & & {$[0.007]$} \\
\hline \multicolumn{5}{|l|}{ Differences in: } \\
\hline \multirow[t]{2}{*}{ Religious affiliation } & & & $0.019 * * *$ & $0.019 * * *$ \\
\hline & & & {$[0.005]$} & {$[0.005]$} \\
\hline \multirow[t]{2}{*}{ Income } & & & 0.0001 & 0.0001 \\
\hline & & & {$[0.001]$} & {$[0.001]$} \\
\hline \multirow[t]{2}{*}{ Education } & & & $0.018 * *$ & $0.018 * *$ \\
\hline & & & {$[0.006]$} & {$[0.006]$} \\
\hline \multirow[t]{2}{*}{ Age } & & & $-0.001 * * *$ & $-0.001 * * *$ \\
\hline & & & {$[0.0002]$} & {$[0.0002]$} \\
\hline \multirow[t]{2}{*}{ Industrial index } & & & 0.004 & 0.004 \\
\hline & & & {$[0.004]$} & {$[0.004]$} \\
\hline \multirow[t]{2}{*}{ Gender } & & & 0.003 & 0.003 \\
\hline & & & {$[0.005]$} & {$[0.005]$} \\
\hline \multirow[t]{2}{*}{ Occupations } & & & $0.026 * * *$ & $0.026 * * *$ \\
\hline & & & {$[0.007]$} & {$[0.007]$} \\
\hline Observations & 547581 & 547581 & 535095 & 535095 \\
\hline R-squared & 0.452 & 0.452 & 0.447 & 0.447 \\
\hline
\end{tabular}


Table B2: Influence of Different Empires, Current Democratization and EU Integration

\begin{tabular}{|c|c|c|c|}
\hline & 1 & 2 & 3 \\
\hline & \multicolumn{3}{|c|}{ Manhattan Distance General Trust } \\
\hline \multirow[t]{2}{*}{ Same Empire more 100 years } & & $-0.040 * * *$ & $-0.041 * * *$ \\
\hline & & {$[0.008]$} & {$[0.007]$} \\
\hline \multirow{2}{*}{ Habsburg more 100 years } & 0.009 & & \\
\hline & [0.009] & & \\
\hline \multirow[t]{2}{*}{ Ottoman more than 100 years } & $-0.091 * * *$ & & \\
\hline & {$[0.001]$} & & \\
\hline \multirow[t]{2}{*}{ Prussia more than 100 years } & $-0.041 * *$ & & \\
\hline & {$[0.017]$} & & \\
\hline \multirow[t]{2}{*}{ Russian Empire more than 100 years } & $0.048^{* *}$ & & \\
\hline & {$[0.010]$} & & \\
\hline \multirow[t]{2}{*}{ Distance } & $0.029 * * *$ & $0.029 * * *$ & $0.027 * * *$ \\
\hline & {$[0.004]$} & [0.004] & {$[0.004]$} \\
\hline \multirow[t]{2}{*}{ Democracy difference } & & $0.003 *$ & \\
\hline & & [0.001] & \\
\hline \multirow[t]{2}{*}{ EU } & & & -0.004 \\
\hline & & & [0.009] \\
\hline \multirow{2}{*}{ EU-EU candidates } & & & -0.036 \\
\hline & & & {$[0.029]$} \\
\hline \multirow[t]{2}{*}{ EU candidates } & & & $0.050^{* * *}$ \\
\hline & & & {$[0.010]$} \\
\hline Socio-demo and eco controls & yes & yes & yes \\
\hline Same country & yes & yes & yes \\
\hline Contiguous & yes & yes & yes \\
\hline Observations & 535095 & 535095 & 535095 \\
\hline R-squared & 0.448 & 0.447 & 0.449 \\
\hline
\end{tabular}

Notes to Table B1 and B2: All dependent variables are Manhattan Distance measures of dissimilarity between PSU pairs. "Distance" is expressed as the logarithm of the physical distance between PSUs in km. The Same Empire... dummies takes value 1 if both PSUs have belonged to the same Empire for the number of years indicated. Same Country and Contiguity are dummy variables that take value 1 if members of the pair belong to, respectively, the same country or adjacent countries. Socio-demo and eco controls include dissimilarity between pairs of PSUs in terms of religious affiliation, social class composition, education, age, industrial index and occupations. Democracy difference is the difference in Polity IV scores between the respective countries where the PUSs are located. It is 0 if both members are in the same country. $E U$ takes value one if both member of the PSU pair belongs to countries that are EU members. $E U$ candidates takes value one if both member of the PSU pair belongs to countries that are EU. $E U$-candidate $E U$ takes value one if one PSU belongs to a member states and the other to a candidate country.

All regressions include a constant and control for location fixed effects. Robust standard errors are adjusted for clustering on any observation which contains either member of a pair (multi-way 
clustering by each member of the pair following the Cameron et al. (2010) method). *** indicates significance at $1 \%, * *$ at $5 \%, *$ at $10 \%$.

Source: Life in Transition Survey 2009; Periodical Atlas of Europe 1300-2000.

Table B3: Gravity Model applied to Economic Occupations: Baseline results

\begin{tabular}{|c|c|c|c|c|c|}
\hline & 1 & 2 & 3 & 4 & 5 \\
\hline Dependent variable: & \multicolumn{5}{|c|}{ MD Occupations } \\
\hline \multirow[t]{2}{*}{ Distance } & & $0.015 * * *$ & & $0.008 * * *$ & $0.010 * * *$ \\
\hline & & {$[0.002]$} & & {$[0.002]$} & {$[0.003]$} \\
\hline \multirow[t]{2}{*}{ Same Empire } & & & $-0.033 * * *$ & $-0.027 * * *$ & $-0.027 * * *$ \\
\hline & & & {$[0.005]$} & {$[0.005]$} & {$[0.005]$} \\
\hline \multicolumn{6}{|l|}{ Differences in: } \\
\hline \multirow[t]{2}{*}{ Religious affiliation } & $0.036^{* * *}$ & $0.035 * * *$ & $0.034 * * *$ & $0.033 * * *$ & $0.034 * * *$ \\
\hline & {$[0.004]$} & {$[0.004]$} & {$[0.004]$} & {$[0.004]$} & {$[0.004]$} \\
\hline \multirow[t]{2}{*}{ income } & $0.074 * * *$ & $0.074 * * *$ & $0.074 * * *$ & $0.074 * * *$ & $0.074 * * *$ \\
\hline & {$[0.007]$} & {$[0.007]$} & {$[0.007]$} & {$[0.007]$} & {$[0.007]$} \\
\hline \multirow[t]{2}{*}{ education } & $0.151 * * *$ & $0.150 * * *$ & $0.150 * * *$ & $0.150 * * *$ & $0.150 * * *$ \\
\hline & {$[0.008]$} & {$[0.008]$} & {$[0.008]$} & {$[0.008]$} & {$[0.008]$} \\
\hline \multirow[t]{2}{*}{ age } & $0.015 * * *$ & $0.015 * * *$ & $0.015 * * *$ & $0.015 * * *$ & $0.015 * * *$ \\
\hline & {$[0.0006]$} & {$[0.0006]$} & {$[0.0006]$} & {$[0.0006]$} & {$[0.0006]$} \\
\hline \multirow[t]{2}{*}{ industrial index } & $0.007 * *$ & $0.007 * *$ & $0.007 * *$ & $0.007 * *$ & $0.007 * *$ \\
\hline & {$[0.002]$} & {$[0.002]$} & {$[0.002]$} & {$[0.002]$} & {$[0.002]$} \\
\hline \multirow[t]{2}{*}{ gender } & $0.049 * * *$ & $0.049 * * *$ & $0.049 * * *$ & $0.049 * * *$ & $0.049 * * *$ \\
\hline & {$[0.010]$} & {$[0.010]$} & {$[0.010]$} & {$[0.010]$} & {$[0.010]$} \\
\hline \multirow[t]{2}{*}{ Same Country } & $-0.018 * * *$ & & & & 0.009 \\
\hline & {$[0.005]$} & & & & {$[0.006]$} \\
\hline \multirow[t]{2}{*}{ Contiguous } & $-0.017 * * *$ & & & & -0.002 \\
\hline & {$[0.003]$} & & & & {$[0.003]$} \\
\hline Observations & 535095 & 535095 & 547581 & 547581 & 547581 \\
\hline R-squared & 0.586 & 0.587 & 0.587 & 0.588 & 0.588 \\
\hline
\end{tabular}


Table B4: Gravity Model applied to Economic Occupations: extensions

\begin{tabular}{|c|c|c|c|c|}
\hline & 1 & 2 & 3 & 4 \\
\hline & \multicolumn{4}{|c|}{ MD Occupations } \\
\hline \multirow[t]{2}{*}{ Distance } & $0.009 * * *$ & $0.006^{* *}$ & $0.008^{* *}$ & $0.012 * * *$ \\
\hline & {$[0.003]$} & {$[0.003]$} & {$[0.003]$} & {$[0.002]$} \\
\hline \multirow[t]{2}{*}{ Same Empire 100 to 200 years } & -0.009 & & & \\
\hline & {$[0.005]$} & & & \\
\hline \multirow[t]{2}{*}{ Same Empire 200 to 400 years } & $-0.037 * * *$ & & & \\
\hline & {$[0.010]$} & & & \\
\hline \multirow[t]{2}{*}{ Same Empire more than 400 years } & $-0.037 * * *$ & & & \\
\hline & {$[0.008]$} & & & \\
\hline \multirow[t]{2}{*}{ Same Empire more than 100 years } & & $-0.030 * * *$ & $-0.025^{* *}$ & $-0.018 * * *$ \\
\hline & & {$[0.005]$} & {$[0.005]$} & {$[0.005]$} \\
\hline \multirow[t]{2}{*}{ USSR } & & $-0.018^{* *}$ & & \\
\hline & & {$[0.002]$} & & \\
\hline \multirow[t]{2}{*}{ Yugoslavia } & & $-0.015^{* *}$ & & \\
\hline & & {$[0.006]$} & & \\
\hline \multirow[t]{2}{*}{ EU } & & & $-0.015^{*}$ & \\
\hline & & & {$[0.006]$} & \\
\hline \multirow[t]{2}{*}{ EU-EU candidates } & & & $0.026^{* * *}$ & \\
\hline & & & {$[0.001]$} & \\
\hline \multirow[t]{2}{*}{ EU candidates } & & & -0.002 & \\
\hline & & & [0.014] & \\
\hline \multirow[t]{2}{*}{ Democracy difference } & & & & $0.003 * * *$ \\
\hline & & & & [0.0001] \\
\hline Same country & yes & yes & yes & yes \\
\hline Contiguity & yes & yes & yes & yes \\
\hline Socio-demo and eco controls & yes & yes & yes & yes \\
\hline Observations & 535095 & 535095 & 535095 & 535095 \\
\hline R-squared & 0.604 & 0.588 & 0.588 & 0.600 \\
\hline
\end{tabular}

Notes to Table B3 and B4: see notes to Table B1 and B2. Socio-demo and eco controls include dissimilarity between pairs of PSUs in terms of religious affiliation, social class composition, education, age, industrial index.

Source: Life in Transition Survey 2009; Periodical Atlas of Europe 1300-2000. 


\section{Additional References}

Bisin, Alberto and Thierry Verdier 2001. "The Economics of Cultural Transmission and the Dynamics of Preferences.” Journal of Economic Theory, 97(2): 298-319.

Head, Thierry and Keith Head, 2008. "Detection of local interactions from the spatial pattern of names in France." Journal of Regional Science, 48: 67-95.

Tabellini, Guido 2010 "Culture and Institutions: Economic Development in the Regions of Europe.” Journal of the European Economic Association, 8(4): 677-716. 